\title{
FAKTOR YANG MEMPENGARUHI NILAI PERUSAHAAN PERBANKAN YANG TERDAFTAR DI BEI TAHUN 2017-2019
}

\author{
Christina Audrey Putri \\ Program Studi Akuntansi \\ Fakultas Ekonomi Universitas Katolik Parahyangan \\ Email: $\underline{6041801024 @ \text { student.unpar.ac.id }}$
}

\begin{abstract}
Globalization causes increasingly rapid and intense competition between companies so that companies must continue to improve their performance to compete and survive for a long time. The banking sector is no exception. Banking sector stocks are stocks that are chosen by many investors when they are going to invest. Before making investment decisions in the capital market, investors need information about the value of the company or the value of shares which can be obtained by reading and analyzing financial statements. Many factors can determine the value of the company, including profitability, company size, and dividend policy. This study aims to determine the effect of profitability, firm size, and dividend policy on firm value. The companies that are the unit of analysis for this research are banking companies listed on the Indonesia Stock Exchange (IDX) in 2017-2019. Data were collected by purposive sampling based on predetermined criteria. The secondary data obtained were then processed by descriptive statistical methods and multiple linear regression analysis. The results of the study show that profitability variables can be proven to affect firm value, while firm size and dividend policy variables cannot be proven to affect the value of banking companies listed on the Indonesia Stock Exchange in 2017-2019. However, simultaneously, profitability, company size, and dividend policy can be proven to affect the value of banking companies listed on the IDX in 2017-2019.
\end{abstract}

Keywords: Profitability, Firm Size, Dividend Policy, Firm Value

\begin{abstract}
ABSTRAK
Globalisasi menyebabkan semakin pesat dan ketatnya persaingan antar perusahaan sehingga perusahaan harus terus meningkatkan kinerjanya agar dapat bersaing dan bertahan lama. Tak terkecuali perusahaan sektor perbankan. Saham sektor perbankan merupakan saham-saham yang banyak dipilih oleh para investor ketika akan melakukan investasi. Sebelum melakukan keputusan investasi di pasar modal, investor memerlukan informasi tentang nilai perusahaan atau nilai saham yang dapat diperoleh dengan membaca dan melakukan analisis laporan keuangan. Terdapat banyak faktor yang dapat menentukan nilai perusahaan, di antaranya adalah profitabilitas, ukuran perusahaan dan kebijakan dividen. Penelitian ini bertujuan untuk mengetahui pengaruh profitabilitas, ukuran perusahaan, dan kebijakan dividen terhadap nilai perusahaan. Perusahaan yang menjadi unit analisis penelitian ini adalah perusahaan perbankan yang terdaftar di Bursa Efek Indonesia (BEI) tahun 2017-2019. Pengumpulan data dilakukan dengan cara purposive sampling berdasarkan kriteria yang telah ditentukan. Data sekunder yang diperoleh kemudian diolah dengan metode statistik deskriptif dan analisis regresi linear berganda. Hasil penelitian menunjukkan variabel profitabilitas dapat dibuktikan berpengaruh terhadap nilai perusahaan, sedangkan variabel ukuran perusahaan dan kebijakan dividen tidak dapat dibuktikan berpengaruh terhadap nilai perusahaan perbankan yang terdaftar di BEI tahun 2017-2019. Namun, secara simultan, profitabilitas, ukuran perusahaan, dan kebijakan dividen dapat dibuktikan berpengaruh terhadap nilai perusahaan perbankan yang terdaftar di BEI tahun 2017-2019.
\end{abstract}

Kata Kunci: Profitabilitas, Ukuran Perusahaan, Kebijakan Dividen, Nilai Perusahaan JEL: M41 


\section{PENDAHULUAN}

Di era globalisasi seperti sekarang ini, dunia usaha berkembang semakin pesat, semakin banyak pula perusahaan go public muncul di berbagai sektor. Hal ini menyebabkan semakin pesat dan ketatnya persaingan antar perusahaan sehingga perusahaan harus terus meningkatkan kinerjanya agar dapat bersaing dan bertahan lama. Tak terkecuali perusahaan sektor perbankan. Saham sektor perbankan juga merupakan saham-saham yang banyak dipilih oleh para investor ketika akan melakukan investasi. Sebelum melakukan keputusan investasi di pasar modal, investor memerlukan informasi tentang nilai perusahaan atau nilai saham yang dapat diperoleh dengan membaca dan melakukan analisis laporan keuangan. Laporan keuangan sendiri terdiri dari laporan laba rugi, laporan arus kas, laporan perubahan modal, laporan neraca serta catatan atas laporan keuangan. Dengan menganalisis laporan keuangan perusahaan terkait, diharapkan para investor dapat menilai dan memperkirakan kondisi keuangan perusahaan sehingga pada akhirnya dapat membantu para investor dalam mengambil keputusan investasi yang tepat yakni berinvestasi pada saham perusahaan-perusahaan yang prospeknya baik dan menguntungkan.

Salah satu tujuan utama perusahaan, termasuk juga bank, yaitu untuk memaksimumkan laba serta memaksimumkan kesejahteraan pemegang saham (Berliani, 2020). Salah satu cara memaksimumkan kesejahteraan pemegang saham adalah melalui peningkatan nilai perusahaan (Salvatore, 2005). Perusahaan harus bisa meningkatkan nilai perusahaan karena semakin tinggi nilai perusahaan akan membentuk persepsi baik investor terhadap perusahaan sehingga investor memiliki ketertarikan dan kepercayaan untuk berinvestasi. Nilai perusahaan merupakan persepsi investor terhadap tingkat keberhasilan perusahaan yang sering dikaitkan dengan harga saham dan profitabilitas (Aisyatul, 2014), maka informasi mengenai nilai perusahaan merupakan hal yang sangat penting, baik bagi perusahaan dalam rangka menilai kinerjanya, maupun bagi investor dalam kaitannya dengan keputusan investasi.

Terdapat banyak faktor yang dapat menentukan nilai perusahaan, di antaranya adalah profitabilitas, ukuran perusahaan dan kebijakan dividen (Suffah \& Riduwan, 2016). Profitabilitas adalah kemampuan perusahaan untuk menghasilkan laba dengan menggunakan sumber-sumber yang dimiliki seperti aktiva, modal atau penjualan perusahaan (Sudana, 2011). Sementara, ukuran perusahaan dapat diartikan sebagai besar kecilnya perusahaan dilihat dari besarnya nilai ekuitas, nilai perusahaan, ataupun hasil nilai total aktiva dari suatu perusahaan (Riyanto, 2001). Dan faktor lainnya, yaitu kebijakan dividen yang merupakan keputusan investasi dalam hal pembagian laba yang dapat dibagikan dalam bentuk dividen kepada pemegang saham atau akan dipergunakan kembali oleh perusahaan di masa yang akan datang dalam bentuk laba ditahan (Berliani, 2020). Berdasarkan latar belakang tersebut, maka tujuan penelitian yang ingin dicapai adalah sebagai berikut: 1 . untuk mengetahui apakah profitabilitas berpengaruh terhadap nilai perusahaan perbankan yang terdaftar di BEI tahun 2017-2019; 2. untuk mengetahui apakah ukuran perusahaan berpengaruh terhadap nilai perusahaan perbankan yang terdaftar di BEI tahun 2017-2019; 3. Untuk mengetahui apakah kebijakan dividen berpengaruh terhadap nilai perusahaan perbankan yang terdaftar di BEI tahun 2017-2019; dan 4. untuk mengetahui apakah profitabilitas, ukuran perusahaan, dan kebijakan dividen berpengaruh terhadap nilai perusahaan perbankan yang terdaftar di BEI tahun 2017-2019.

\subsection{Tinjauan Pustaka}

\section{Profitabilitas}

Profitabilitas adalah kemampuan perusahaan untuk menghasilkan laba dengan menggunakan sumber-sumber yang dimiliki seperti aktiva, modal atau penjualan perusahaan 
(Sudana, 2011). Profitabilitas juga dapat menunjukkan kemampuan perusahaan untuk menghasilkan laba pada masa mendatang dan merupakan indikator dari keberhasilan operasi perusahaan (Kusumawati, 2005). Analisis mengenai profitabilitas sangat penting bagi kreditor dan investor. Bagi kreditor, laba merupakan sumber pembayaran bunga dan pokok pinjaman. Sedangkan bagi investor, laba merupakan salah satu faktor penentu perubahan nilai efek (Noviliyan, 2016).

Rasio profitabilitas terdiri atas dua jenis yaitu, rasio yang berkaitan dengan penjualan, yaitu Gross Profit Margin (GPM) dan Net Profit Margin (NPM), serta rasio yang berkaitan dengan investasi, yaitu Return on Asset (ROA) dan Return on Equity (ROE) (James \& Wachowicz, 2005). Dalam penelitian ini, rasio profitabilitas yang digunakan adalah ROA.

\section{Return on Asset}

Return on Asset (ROA) menunjukkan kemampuan perusahaan dalam menghasilkan laba atas aktiva yang dipergunakan (Margareta, 2005). Semakin tinggi rasio ini, semakin baik keadaan suatu perusahaan. Apabila tingkat ROA itu rendah, tidak selalu berarti buruk. Hal tersebut dapat diakibatkan oleh keputusan yang disengaja untuk menggunakan utang dalam jumlah besar, beban bunga yang tinggi menyebabkan laba bersih menjadi relatif rendah (Brigham \& Houston, 2007). Return on Asset dihitung dengan membagi laba bersih setelah pajak dengan total aktiva (Mulyadi, 2006).

$$
\mathrm{ROA}=\frac{\text { Laba Bersih Setelah Pajak }}{\text { Total Aktiva }}
$$

\section{Ukuran Perusahaan}

Ukuran perusahaan adalah suatu skala di mana dapat diklasifikasikan besar kecilnya perusahaan menurut berbagai cara antara lain dengan total aktiva, log size, nilai pasar saham, dan lain-lain (Husnan, 2008). Ukuran perusahaan dapat menggambarkan besar kecilnya suatu perusahaan yang ditunjukkan oleh total aktiva dan jumlah penjualan (Dewi \& Wirajaya, 2013). Ukuran perusahaan dianggap mampu mempengaruhi nilai perusahaan karena semakin besar ukuran maka akan semakin mudah pula perusahaan memperoleh sumber pendanaan, baik yang bersifat internal maupun eksternal (Prasetyorini, 2013).

Semakin besar ukuran perusahaan, biasanya informasi yang tersedia untuk investor dalam pengambilan keputusan sehubungan dengan investasi dalam saham perusahaan tersebut semakin banyak (Berliani, 2020). Ukuran perusahaan diukur berdasarkan jumlah aset yang dimiliki perusahaan sesuai dengan ketentuan BAPEPAM No.11/PM/1997, yang menyatakan bahwa perusahaan menengah atau kecil adalah perusahaan yang memiliki jumlah kekayaan (total asset) tidak lebih dari 100 miliar rupiah (Berliani, 2020). Pada penelitian ini nilai perusahaan akan ditentukan dengan rumus:

$$
\text { Size }=\ln (\text { Total Aset })
$$

\section{Kebijakan Dividen}

Dividen merupakan suatu pembayaran yang sifatnya permanen atas modal yang diserahkan oleh pemegang saham atau pemilik perusahaan (Syamsuddin, 2011). Atau dapat dikatakan bahwa kebijakan dividen merupakan keputusan investasi dalam hal pembagian laba yang dapat dibagikan dalam bentuk dividen kepada pemegang saham atau akan dipergunakan kembali oleh perusahaan di masa yang akan datang dalam bentuk laba ditahan (Berliani, 2020). Kebijakan dividen dapat diukur dengan cara menghitung Dividend Payout Ratio (DPR) dengan rumus (Analisa, 2011): 


$$
\text { DPR }=\frac{\text { Dividen per Lembar Saham }}{\text { Laba per Lembar Saham }}
$$

\section{Nilai Perusahaan}

Nilai perusahaan (firm value) merupakan nilai ekonomi yang mencakup modal ekuitas dan modal utang perusahaan (Brigham \& Houston, 2011). Kinerja perusahaan yang dicerminkan oleh harga saham yang dibentuk oleh permintaan dan penawaran pasar modal yang merefleksikan penilaian masyarakat terhadap kinerja perusahaan juga dapat dikatakan sebagai nilai perusahaan (Harmono, 2014). Semakin tinggi harga saham semakin tinggi pula nilai perusahaan. Nilai perusahaan yang terus meningkat dapat menarik para investor untuk menanamkan modalnya di perusahaan tersebut (Siregar, Dalimunthe, \& Trijuniyanto, 2019).

Nilai perusahaan juga merupakan harga yang bersedia dibayar oleh calon pembeli apabila perusahaan dijual (Husnan \& Pudjiastuti, 2015). Sementara, Sujoko dan Soebiantoro (2007) menyatakan bahwa nilai perusahaan merupakan persepsi investor terhadap perusahaan yang selalu dikaitkan dengan harga saham. Terdapat beberapa metode yang dapat digunakan untuk mengukur nilai perusahaan, yaitu: Price Earning Ratio (PER), Price to Book Value (PBV), dan Tobin's Q. dalam penelitian ini digunakan Tobin's Q.

\section{Tobin's Q}

Tobin's Q menunjukkan estimasi pasar keuangan saat ini tentang nilai hasil pengembalian dari setiap dolar investasi di masa depan (Suffah \& Riduwan, 2016). Tobin's Q dihitung dengan membandingkan rasio nilai pasar saham perusahaan ditambah dengan utang lalu membandingkan dengan total aset perusahaan (Smithers \& Wright, 2007).

$$
\text { Tobin's Q }=\frac{\text { MVE }+ \text { Total Debt }}{\text { Total Asset }}
$$

Dimana:

MVE (Market Value Equity) = Nilai pasar saham yang diperoleh dari jumlah saham beredar $\mathrm{x}$ harga saham pada akhir tahun atau closing price

Total Debt

= Nilai total kewajiban perusahaan

Total Asset

= Nilai total aktiva perusahaan

\section{Perusahaan Perbankan}

Pada Undang-undang Nomor 10 Tahun 1998 tentang Perbankan, bank disebutkan sebagai badan usaha yang menghimpun dana dari masyarakat dalam bentuk simpanan dan menyalurkannya kepada masyarakat dalam bentuk kredit dan atau bentuk-bentuk lainnya dalam rangka meningkatkan taraf hidup masyarakat. Secara sederhana bank dapat diartikan sebagai lembaga keuangan yang kegiatan usahanya adalah menghimpun dana dari masyarakat dan menyalurkan kembali dana tersebut ke masyarakat serta memberikan jasa-jasa bank lainnya (Kasmir, 2008). Fungsi bank dalam perekonomian suatu negara dapat diklasifikasikan sebagai berikut (Adli \& Hidayat, 2012) :

1) Agent of Trust: artinya aktivitas bank sebagai financial intermediary, menjalankan fungsinya atas dasar kepercayaan yang diterima dari masyarakat. Kepercayaan yang diberikan berupa amanat agar bank mengelola dan mengamankan dana yang disimpan masyarakat di bank tersebut. 
2) Agent of development : untuk mewujudkan pembangunan dan kesejahteraan dalam perekonomian, bank dianggap sebagai lembaga yang cukup berperan signifikan. Hal ini dikarenakan aktivitas bank sebagai financial intermediary dapat mempertemukan sektor riil dan sektor moneter untuk berinteraksi demi mendukung proses pembangunan.

3) Agent of service : aktivitas perbankan tidak hanya terbatas dalam hal menghimpun dana dan menyalurkan dana di tengah masyarakat. Bank juga memberikan layanan atau jasa terkait kegiatan perekonomian masyarakat.

\subsection{Kerangka Pemikiran dan Pengembangan Hipotesis}

Dalam penelitian ini terdapat tiga (3) variabel independen, yaitu profitabilitas $\left(\mathrm{X}_{1}\right)$, ukuran perusahaan $\left(\mathrm{X}_{2}\right)$ dan kebijakan dividen $\left(\mathrm{X}_{3}\right)$. Sedangkan variabel dependen dalam penelitian ini adalah nilai perusahaan $(\mathrm{Y})$.

\section{Pengaruh Profitabilitas terhadap Nilai Perusahaan Perbankan yang terdaftar di Bursa Efek Indonesia (BEI).}

Profitabilitas adalah kemampuan perusahaan untuk menghasilkan laba dengan menggunakan sumber-sumber yang dimiliki seperti aktiva, modal atau penjualan perusahaan (Sudana, 2011). Laba yang tinggi akan memberikan sinyal positif bagi investor. Peningkatan laba mencerminkan bahwa perusahaan mempunyai kinerja yang baik, sehingga menimbulkan sentimen positif dari investor dan dapat membuat harga saham perusahaan mengalami peningkatan (Berliani, 2020). Profitabilitas dapat dihitung dengan ROA (return on asset). ROA dapat menunjukkan kemampuan perusahaan dalam menghasilkan laba atas aktiva yang dipergunakan (Margareta, 2005). Semakin tinggi rasio ini, semakin baik keadaan suatu perusahaan. Profitabilitas yang tinggi akan memberikan indikasi prospek perusahaan yang baik sehingga dapat memicu investor untuk ikut meningkatkan permintaan saham. Selanjutnya permintaan saham yang meningkat akan menyebabkan nilai perusahaan yang meningkat (Prasetyorini, 2013). Berdasarkan uraian di atas, maka dapat dirumuskan hipotesis sebagai berikut:

$\mathrm{H}_{1}$ : Profitabilitas berpengaruh terhadap nilai perusahaan perbankan yang terdaftar di Bursa Efek Indonesia (BEI).

\section{Pengaruh Ukuran Perusahaan terhadap Nilai Perusahaan Perbankan yang terdaftar di Bursa Efek Indonesia (BEI).}

Ukuran perusahaan adalah suatu skala di mana dapat diklasifikasikan besar kecilnya perusahaan menurut berbagai cara antara lain dengan total aktiva, log size, nilai pasar saham, dan lain-lain (Husnan, 2008). Ukuran perusahaan dapat menentukan tingkat kemudahan perusahaan dalam memperoleh dana dari pasar modal dan menentukan kekuatan tawar-menawar (bargaining power) dalam kontrak keuangan (Hasnawati \& Sawir, 2015). Salah satu cara dalam meningkatkan nilai perusahaan yaitu dengan memaksimalkan ukuran perusahaan itu sendiri, karena dengan ukuran perusahaan yang besar, yang dapat ditandai dengan kepemilikan aset yang banyak, maka laba akan meningkat pula, sehingga dividen, permintaan saham, serta nilai perusahaan akan meningkat. Berdasarkan uraian di atas, maka dapat dirumuskan hipotesis sebagai berikut:

$\mathrm{H}_{2}$ : Ukuran perusahaan berpengaruh terhadap nilai perusahaan perbankan yang terdaftar di Bursa Efek Indonesia (BEI). 


\section{Pengaruh Kebijakan Dividen terhadap Nilai Perusahaan Perbankan yang terdaftar di Bursa Efek Indonesia (BEI).}

Kebijakan dividen menyangkut keputusan untuk membagikan laba atau menahannya dengan tujuan untuk diinvestasikan kembali di dalam perusahaan (Darmanto, 2015). Pembagian dividen dapat dijadikan sebuah informasi oleh calon investor sebelum melakukan investasi (Romadhani, Saifi, \& Nuzula, 2020). Keputusan dengan membagikan dividen yang besar juga secara otomatis mempengaruhi ketertarikan investor. Pembagian dividen yang dilakukan oleh perusahaan juga dapat mencerminkan kinerja perusahaan yang baik dan pembayaran itu dapat mengurangi risiko kegagalan tingkat pengembalian saham terhadap pemegang (Romadhani, Saifi, \& Nuzula, 2020). Dengan meningkatnya laba serta kinerja perusahaan yang baik yang ditunjukkan dengan kebijakan pembagian dividen, nilai perusahaan pun akan meningkat. Berdasarkan uraian di atas, maka dapat dirumuskan hipotesis sebagai berikut:

$\mathrm{H}_{3}$ : Kebijakan dividen berpengaruh terhadap nilai perusahaan perbankan yang terdaftar di Bursa Efek Indonesia (BEI).

\section{Pengaruh Profitabilitas, Ukuran Perusahaan, dan Kebijakan Dividen terhadap Nilai Perusahaan Perbankan yang terdaftar di Bursa Efek Indonesia (BEI).}

Tinggi rendahnya tingkat profitabilitas suatu perusahaan akan berdampak pada nilai perusahaan, selain itu dengan meningkatnya nilai perusahaan dapat pula mengundang banyak investor yang akan berinvestasi di perusahaan terkait (Romadhani, Saifi, \& Nuzula, 2020). Firm size merupakan identitas utama yang dapat digunakan untuk mengukur besarnya skala ukuran perusahaan. Semakin besar ukuran sebuah perusahaan maka firm value akan meningkat (Romadhani, Saifi, \& Nuzula, 2020). Dikatakan pula bahwa nilai perusahaan akan dimaksimalkan oleh rasio pembayaran dividen yang tinggi, hal tersebut dikarenakan investor menganggap bahwa risiko dividen tidak sebesar risiko kenaikan biaya modal (Brigham \& Houston, 2007). Menurut Darmanto (2015) dalam penelitiannya, dapat disimpulkan bahwa profitabilitas, ukuran perusahaan dan kebijakan dividen berpengaruh terhadap nilai perusahaan. Berdasarkan uraian di atas, maka dapat dirumuskan hipotesis sebagai berikut:

$\mathrm{H}_{4}$ : Profitabilitas, ukuran perusahaan dan kebijakan dividen berpengaruh terhadap nilai perusahaan perbankan yang terdaftar di Bursa Efek Indonesia (BEI).

Gambar 1. Model Penelitian 
(Parhusip, Topowijono, \& Sulasmiyati, 2016)

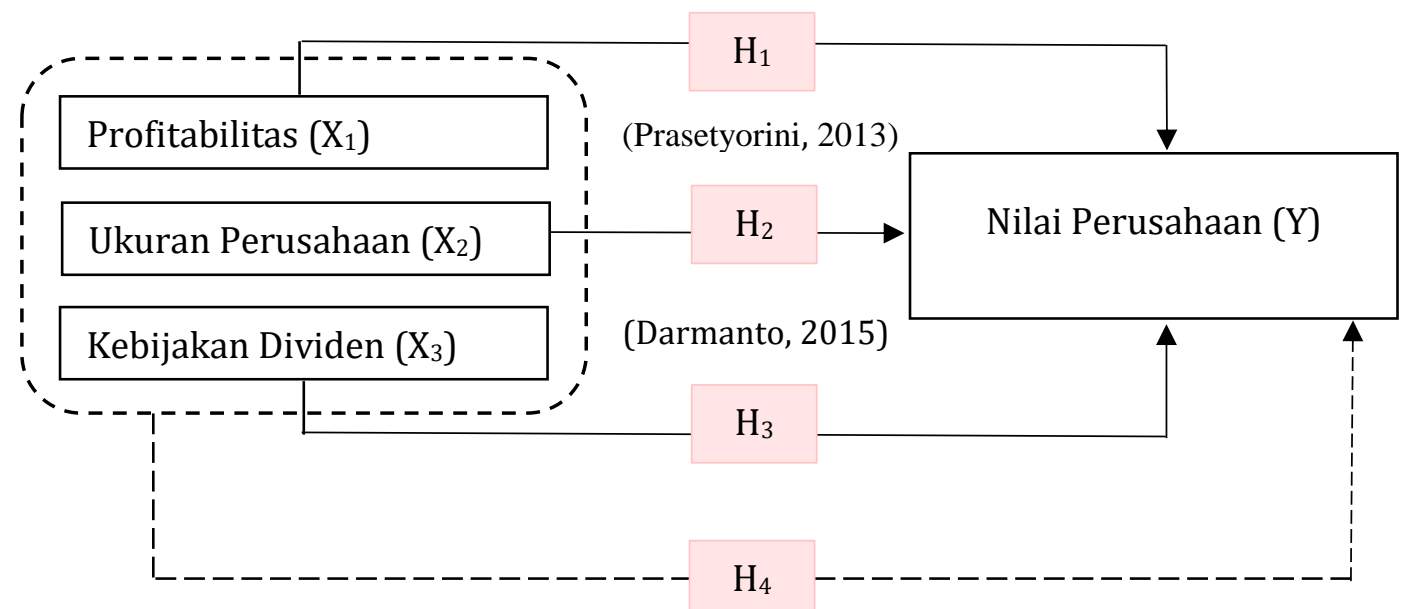

(Berliani, 2020)

Keterangan:

$\mathrm{H}_{1}$ : Profitabilitas berpengaruh terhadap nilai perusahaan perbankan yang terdaftar di Bursa Efek Indonesia (BEI).

$\mathrm{H}_{2}$ : Ukuran perusahaan berpengaruh terhadap nilai perusahaan perbankan yang terdaftar di Bursa Efek Indonesia (BEI).

$\mathrm{H}_{3}$ : Kebijakan dividen berpengaruh terhadap nilai perusahaan perbankan yang terdaftar di Bursa Efek Indonesia (BEI).

$\mathrm{H}_{4}$ : Profitabilitas, ukuran perusahaan, dan kebijakan dividen berpengaruh terhadap nilai perusahaan perbankan yang terdaftar di Bursa Efek Indonesia (BEI).

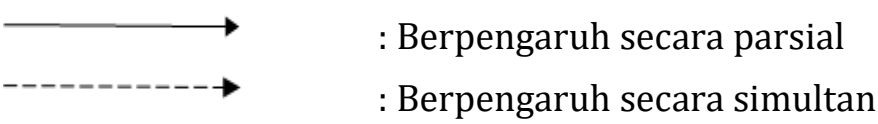

\section{METODE DAN DATA}

Dalam penelitian ini digunakan metode deduktif kuantitatif yang berbentuk kausal atau sebab-akibat. Untuk mendukung penelitian ini digunakan sumber data berupa data sekunder. Data sekunder sendiri merupakan data yang diperoleh atau dikumpulkan oleh orang yang melakukan penelitian dari sumber-sumber yang telah ada (Hasan, 2002). Sumber data sekunder yang digunakan berupa laporan keuangan perusahaan jasa sektor finansial sub-sektor bank tahun 2017-2019 yang terdaftar di Bursa Efek Indonesia melalui website www.idx.co.id dan www.idnfinancials.com. Kemudian untuk mengetahui jumlah perusahaan perbankan, pembagian dividen dan kelengkapan laporan keuangan dilakukan melalui website www.idnfinancials.com yang merupakan platform video dan teknologi untuk Bursa Efek Indonesia. Data yang digunakan bersifat kuantitatif.

Populasi pada penelitian ini adalah perusahaan sub-sektor bank yang terdaftar di Bursa Efek Indonesia (BEI) selama tahun 2017-2019, yakni sebanyak 41 perusahaan. Teknik pengambilan sampel yang digunakan adalah teknik purposive sampling, yaitu teknik penentuan sampel yang berdasarkan kriteria tertentu. Kriteria pengambilan sampel dalam penelitian ini adalah: 
90 | Bina Ekonomi

1. Perusahaan sub-sektor bank yang konsisten terdaftar di Bursa Efek Indonesia selama tahun 2017-2019.

2. Perusahaan yang menerbitkan laporan keuangan secara lengkap untuk periode 2017-2019.

3. Perusahaan yang secara konsisten membagikan dividen setiap tahunnya selama periode 2017-2019.

Berikut ini adalah penggolongan sampel berdasarkan kriteria pengambilan sampel yang digunakan dalam penelitian:

Tabel 1. Kriteria Sampel

\begin{tabular}{|c|l|c|}
\hline No & \multicolumn{1}{|c|}{ Keterangan } & Jumlah \\
\hline 1 & $\begin{array}{l}\text { Perusahaan sub-sektor bank yang konsisten terdaftar di } \\
\text { Bursa Efek Indonesia selama tahun 2017-2019 }\end{array}$ & 41 \\
\hline 2 & $\begin{array}{l}\text { Perusahaan yang tidak menerbitkan laporan keuangan secara } \\
\text { lengkap untuk periode 2017-2019 }\end{array}$ & 0 \\
\hline 3 & $\begin{array}{l}\text { Perusahaan yang tidak secara konsisten membagikan dividen } \\
\text { setiap tahunnya selama periode 2017-2019 }\end{array}$ & 13 \\
\hline \multicolumn{2}{|l}{ Jumlah perusahaan yang memenuhi kriteria sampel } \\
\hline
\end{tabular}

Sumber: www.idnfinancials.com (telah diolah peneliti)

Berdasarkan penggolongan sampel di atas, diperoleh jumlah perusahaan yang memenuhi kriteria sampel sebanyak 13 perusahaan, dengan rincian sebagai berikut:

Tabel 2. Daftar Perusahaan yang Menjadi Sampel Penelitian

\begin{tabular}{|c|l|c|}
\hline No & \multicolumn{1}{|c|}{ Nama Perusahaan } & Kode Saham \\
\hline 1 & PT. Bank Central Asia Tbk & BBCA \\
\hline 2 & PT. Bank Negara Indonesia (Persero) Tbk & BBNI \\
\hline 3 & PT. Bank Rakyat Indonesia (Persero) Tbk & BBRI \\
\hline 4 & PT. Bank Tabungan Negara (Persero) Tbk & BBTN \\
\hline 5 & PT. Bank Danamon Indonesia Tbk & BDMN \\
\hline 6 & $\begin{array}{l}\text { PT. Bank Pembangunan Daerah Jawa Barat dan Banten } \\
\text { Tbk }\end{array}$ & BJBR \\
\hline 7 & PT. Bank Pembangunan Daerah Jawa Timur Tbk & BJTM \\
\hline 8 & PT. Bank Mandiri (Persero) Tbk & BMRI \\
\hline 9 & PT. Bank Bumi Arta Tbk & BNBA \\
\hline 10 & PT. Ban CIMB Niaga Tbk & BNGA \\
\hline 11 & PT. Bank Maybank Indonesia Tbk & BNII \\
\hline 12 & PT. Bank Mega Tbk & MEGA \\
\hline 13 & PT. Bank Woori Saudara Indonesia 1906 Tbk \\
\hline
\end{tabular}

\subsection{Metode Pengolahan Data}

Pengolahan data yang digunakan dalam penelitian ini adalah analisis statistik deskriptif dan uji hipotesis melalui uji statistik parsial dan uji statistik simultan. Adapun teknik pengolahan statistik yang digunakan adalah analisis regresi berganda.

\subsection{Variabel Penelitian}


Variabel yang digunakan dalam penelitian ini terdiri dari dua (2), yakni variabel dependen dan variabel independen.

\section{Variabel Independen}

Variabel independen atau sering disebut juga variabel bebas merupakan variabel yang dapat mempengaruhi variabel lainnya atau bisa disebut variabel terikat. Dalam penelitian ini variabel independen yang digunakan adalah profitabilitas $\left(\mathrm{X}_{1}\right)$, ukuran perusahaan $\left(\mathrm{X}_{2}\right)$, dan kebijakan dividen $\left(\mathrm{X}_{3}\right)$.

\section{Variabel Dependen}

Variabel dependen atau sering disebut juga variabel terikat adalah variabel yang dipengaruhi oleh variabel independen, variabel ini juga biasanya menjadi perhatian utama dalam penelitian. Variabel dependen dalam penelitian ini adalah nilai perusahaan (Y).

\subsection{Operasionalisasi Variabel}

Tabel 2. Operasionalisasi Variabel

\begin{tabular}{|c|c|c|c|}
\hline Variabel & Definisi Operasional & Indikator & Skala \\
\hline $\begin{array}{c}\text { Profitabilitas } \\
\qquad\left(\mathrm{X}_{1}\right)\end{array}$ & $\begin{array}{l}\text { Profitabilitas merupakan rasio } \\
\text { yang menggambarkan kemampuan } \\
\text { perusahaan untuk mendapatkan } \\
\text { laba melalui sumber yang ada } \\
\text { (diukur dengan menggunakan } \\
\text { ROA) (Sofyan, 2015) . }\end{array}$ & ROA $=\frac{\text { Laba Bersih Setelah Pajak }}{\text { Total Aktiva }}$ & Rasio \\
\hline $\begin{array}{c}\text { Ukuran } \\
\text { Perusahaan } \\
\left(\mathrm{X}_{2}\right)\end{array}$ & $\begin{array}{l}\text { Ukuran perusahaan dapat diartikan } \\
\text { sebagai besar kecilnya perusahaan } \\
\text { dilihat dari besarnya nilai ekuitas, } \\
\text { nilai perusahaan, ataupun hasil } \\
\text { nilai total aktiva dari suatu } \\
\text { perusahaan (Riyanto, 2001). }\end{array}$ & Size $=\ln ($ Total Asset $)$ & Rasio \\
\hline $\begin{array}{c}\text { Kebijakan } \\
\text { Dividen }\left(\mathrm{X}_{3}\right)\end{array}$ & $\begin{array}{l}\text { Kebijakan dividen merupakan } \\
\text { keputusan investasi dalam hal } \\
\text { pembagian laba yang dapat } \\
\text { dibagikan dalam bentuk dividen } \\
\text { kepada pemegang saham atau akan } \\
\text { dipergunakan kembali oleh } \\
\text { perusahaan di masa yang akan } \\
\text { datang dalam bentuk laba ditahan } \\
\text { (Berliani, 2020). }\end{array}$ & DPR $=\frac{\text { Dividen per Lembar Saham }}{\text { Laba per Lembar Saham }}$ & Rasio \\
\hline $\begin{array}{c}\text { Nilai } \\
\text { Perusahaan } \\
\text { (Y) }\end{array}$ & $\begin{array}{l}\text { Nilai perusahaan merupakan } \\
\text { persepsi investor terhadap } \\
\text { perusahaan yang selalu dikaitkan } \\
\text { dengan harga saham (Sujoko \& } \\
\text { Soebiantoro, 2007). }\end{array}$ & Tobin's Q $=\frac{\text { MVE }+ \text { Total Debt }}{\text { Total Asset }}$ & Rasio \\
\hline
\end{tabular}

Sumber: olahan dari berbagai sumber

\section{PEMBAHASAN}

\subsection{Hasil Pengumpulan Data}


Dalam penelitian ini, data Return on Asset (ROA) sebagai indikator variabel profitabilitas, data Dividend Payout Ratio (DPR) sebagai indikator variabel kebijakan dividen serta data kapitalisasi pasar yang digunakan untuk menghitung variabel nilai perusahaan diambil dari annual report masing-masing bank sampel untuk periode 2017 hingga 2019, yang didapatkan dari website resmi masing-masing perusahaan. Sementara, data total aset dan total utang yang digunakan untuk menghitung variabel ukuran perusahaan dan nilai perusahaan diperoleh dari laporan keuangan konsolidasi masing-masing bank sampel untuk periode 2017 hingga 2019, yang didapatkan dari website www.idnfinancials.com.

\subsection{Hasil Analisis Statistik Deskriptif}

Tabel 3. Hasil Pengolahan Statistik Deskriptif

\begin{tabular}{|c|c|c|c|}
\hline \multicolumn{2}{|c|}{$\operatorname{ROA}\left(\mathrm{X}_{1}\right)$} & \multicolumn{2}{|c|}{ Size $\left(\mathrm{X}_{2}\right)$} \\
\hline Mean & 2,443589744 & Mean & 32,87179487 \\
\hline Standard Error & 0,142237512 & Standard Error & 0,236368977 \\
\hline Median & 2,47 & Median & 32,86 \\
\hline Mode & 1,71 & Mode & 34,66 \\
\hline Standard Deviation & 0,888272976 & Standard Deviation & 1,476123786 \\
\hline Minimum & 0,13 & Minimum & 29,58 \\
\hline Maximum & 4 & Maximum & 34,89 \\
\hline Sum & 95,3 & Sum & 1282 \\
\hline Count & 39 & Count & 39 \\
\hline \multicolumn{2}{|c|}{$\operatorname{DPR}\left(\mathrm{X}_{3}\right)$} & \multicolumn{2}{|c|}{ Nilai Perusahaan (Y) } \\
\hline Mean & 0,366558974 & Mean & 1,077948718 \\
\hline Standard Error & 0,023674462 & Standard Error & 0,029892248 \\
\hline Median & 0,35 & Median & 1,03 \\
\hline Mode & 0,2 & Mode & 0,99 \\
\hline Standard Deviation & 0,147846969 & Standard Deviation & 0,186677029 \\
\hline Minimum & 0,1 & Minimum & 0,88 \\
\hline Maximum & 0,6 & Maximum & 1,7 \\
\hline Sum & 14,2958 & Sum & 42,04 \\
\hline Count & 39 & Count & 39 \\
\hline
\end{tabular}

Sumber: Hasil olahan statistik

Tabel 3 di atas menunjukkan hasil olahan statistik deskriptif dengan menggunakan data periode 2017 hingga 2019 dari 13 bank sampel yang diolah menggunakan Microsoft Excel. Berdasarkan tabel tersebut, untuk variabel independen pertama, yaitu profitabilitas yang diukur dengan indikator ROA, diketahui bahwa nilai minimum dari keseluruhan data adalah 0,13 sedangkan nilai maksimum 4, dengan rata-rata nilai (mean) 2,444 dan standar deviasi 0,888. Dapat dilihat bahwa nilai rata-rata ROA lebih besar dibandingkan dengan standar deviasinya yang menandakan bahwa ROA memiliki tingkat variasi data yang rendah atau data bersifat homogen.

Untuk variabel independen kedua, yaitu ukuran perusahaan, diketahui bahwa nilai minimum dari keseluruhan data adalah 29,58 sedangkan nilai maksimum 34,89, dengan rata-rata nilai (mean) 32,872 dan standar deviasi 1,476. Dapat dilihat bahwa nilai rata-rata size lebih besar dibandingkan dengan standar deviasinya yang menandakan bahwa size memiliki tingkat variasi data yang rendah atau data bersifat homogen.

Untuk variabel independen ketiga, yaitu kebijakan dividen yang diukur dengan indikator DPR, diketahui bahwa nilai minimum dari keseluruhan data adalah 0,1 sedangkan nilai 
maksimum 0,6, dengan rata-rata nilai (mean) 0,367 dan standar deviasi 0,148. Dapat dilihat bahwa nilai rata-rata DPR lebih besar dibandingkan dengan standar deviasinya yang menandakan bahwa kebijakan dividen memiliki tingkat variasi data yang rendah atau data bersifat homogen.

Untuk variabel dependen, yaitu nilai perusahaan yang diukur dengan indikator Tobin's $Q$, diketahui bahwa nilai minimum dari keseluruhan data adalah 0,88 sedangkan nilai maksimum 1,7, dengan rata-rata nilai (mean) 1,078 dan standar deviasi 0,187. Dapat dilihat bahwa nilai ratarata nilai perusahaan lebih besar dibandingkan dengan standar deviasinya yang menandakan bahwa variabel nilai perusahaan memiliki tingkat variasi data yang rendah atau data bersifat homogen.

\subsection{Hasil Uji Hipotesis}

\section{Uji Statistik T}

Dalam penelitian ini, dilakukan pengujian statistik t untuk membuktikan apakah variabel independen secara parsial berpengaruh terhadap variabel dependen. Uji statistik $\mathrm{t}$ dilakukan dengan tingkat kesalahan penelitian sebesar 5\% dan tingkat kepercayaan 95\%. Nilai signifikansi ( $p$-value) dari masing-masing variabel independen akan akan dibandingkan dengan tingkat kesalahan penelitian $(0,05)$. Jika, $p$-value lebih kecil dari tingkat kesalahan, maka dapat dikatakan bahwa variabel independen secara parsial dapat dibuktikan berpengaruh terhadap variabel dependen dan sebaliknya, jika, $p$-value lebih besar dari tingkat kesalahan, maka dapat dikatakan bahwa variabel independen secara parsial tidak dapat dibuktikan berpengaruh terhadap variabel dependen.

Tabel 4. Hasil Uji Statistik T

\begin{tabular}{lcrrr}
\hline & \multicolumn{3}{c}{ Standard } & \\
& Coefficients & Error & t Stat & P-value \\
\hline Intercept & 0,122806262 & 0,49116875 & 0,250028655 & 0,804026967 \\
X Variable 1 (ROA) & 0,150200728 & 0,029342859 & 5,118817044 & $1,12008 \mathrm{E}-05$ \\
X Variable 2 (Size) & 0,018866437 & 0,015686883 & 1,202688718 & 0,237170034 \\
& - & & - & \\
X Variable 3 (DPR) & 0,087462456 & 0,156947102 & 0,557273468 & 0,580887309 \\
\hline
\end{tabular}

Sumber: Hasil olahan statistik

Berdasarkan tabel di atas, diperoleh $p$-value untuk variabel:

1. Profitabilitas (ROA) sebesar 0,000011 , yang artinya $p$-value $<0,05$

2. Ukuran Perusahaan (Size) 0,237170 , yang artinya $p$-value $>0,05$

3. Kebijakan Dividen (DPR) 0,580887, yang artinya $p$-value $>0,05$

Perhitungan Uji Statistik T, dapat menjawab hipotesis pertama $\left(\mathrm{H}_{1}\right)$, hipotesis kedua $\left(\mathrm{H}_{2}\right)$ dan hipotesis ketiga $\left(\mathrm{H}_{3}\right)$ dalam penelitian ini, dimana:

\section{Hipotesis Pertama $\left(\mathrm{H}_{1}\right)$}

Berdasarkan hasil perhitungan uji t, diperoleh nilai signifikansi ( $p$-value) untuk variabel profitabilitas $\left(X_{1}\right)$ lebih kecil dari tingkat kesalahan penelitian $(0,00001<0,05)$. Hal ini menunjukkan bahwa secara statistik profitabilitas dapat dibuktikan berpengaruh terhadap nilai perusahaan, sehingga dapat dikatakan bahwa $\mathbf{H}_{0-1}$ ditolak dan $\mathbf{H}_{\mathbf{1 - 1}}$ diterima. 
Hasil penelitian ini sejalan dengan penelitian sebelumnya yang dilakukan oleh Berliani (2020), yang menyatakan bahwa profitabilitas berpengaruh positif dan signifikan terhadap nilai perusahaan secara parsial dan penelitian yang dilakukan oleh Martha, Sogiroh, Magdalena, \& Febsri Susanti (2018), yang menyatakan bahwa profitabilitas berpengaruh secara positif dan signifikan terhadap nilai perusahaan.

\section{Hipotesis Kedua $\left(\mathrm{H}_{2}\right)$}

Berdasarkan hasil perhitungan uji t, diperoleh nilai signifikansi ( $p$-value) untuk variabel ukuran perusahaan $\left(\mathrm{X}_{2}\right)$ lebih besar dari tingkat kesalahan penelitian $(0,237170>0,05)$. Hal ini menunjukkan bahwa secara statistik ukuran perusahaan tidak dapat dibuktikan berpengaruh terhadap nilai perusahaan, sehingga dapat dikatakan bahwa $\mathbf{H}_{\mathbf{0 - 2}}$ diterima dan $\mathbf{H}_{\mathbf{1 - 2}}$ ditolak.

Hasil penelitian ini sejalan dengan penelitian sebelumnya yang dilakukan oleh Wahyudi, Chuzaimah, \& Sugiarti (2016) yang menyatakan bahwa ukuran perusahaan tidak berpengaruh terhadap nilai perusahaan dan mempunyai hubungan positif. Tetapi tidak sejalan dengan penelitian milik Berliani (2020) yang menyatakan bahwa ukuran perusahaan berpengaruh positif dan signifikan terhadap nilai perusahaan secara parsial dan penelitian milik Prasetyorini (2013), yang menyatakan bahwa ukuran perusahaan berpengaruh terhadap nilai perusahaan.

\section{Hipotesis Ketiga $\left(\mathrm{H}_{3}\right)$}

Berdasarkan hasil perhitungan uji t, diperoleh nilai signifikansi ( $p$-value) untuk variabel kebijakan dividen $\left(\mathrm{X}_{3}\right)$ lebih besar dari tingkat kesalahan penelitian $(0,580887>0,05)$. Hal ini menunjukkan bahwa secara statistik kebijakan dividen tidak dapat dibuktikan berpengaruh terhadap nilai perusahaan, sehingga dapat dikatakan bahwa $\mathbf{H}_{\mathbf{0 - 3}}$ diterima dan $\mathbf{H}_{\mathbf{1 - 3}}$ ditolak.

Hasil penelitian ini sejalan dengan penelitian sebelumnya yang dilakukan oleh Berliani (2020), yang menyatakan bahwa kebijakan dividen tidak berpengaruh terhadap nilai perusahaan secara parsial dan penelitian yang dilakukan oleh Maharani (2021), yang menyatakan bahwa kebijakan dividen berpengaruh negatif dan tidak signifikan terhadap nilai perusahaan. Tetapi tidak sejalan dengan penelitian milik Darmanto (2015), yang menyatakan bahwa kebijakan dividen berpengaruh terhadap nilai perusahaan.

\section{Uji Statistik F}

Dalam penelitian ini, dilakukan pengujian statistik $\mathrm{f}$ untuk membuktikan apakah variabel independen secara simultan berpengaruh terhadap variabel dependen. Uji statistik f dilakukan dengan tingkat kesalahan penelitian sebesar 5\% dan tingkat kepercayaan 95\%. Nilai signifikansi (Significance $F$ ) variabel independen akan akan dibandingkan dengan tingkat kesalahan penelitian $(0,05)$. Jika, Significance $F$ lebih kecil dari tingkat kesalahan, maka dapat dikatakan bahwa variabel independen secara simultan dapat dibuktikan berpengaruh terhadap variabel dependen dan sebaliknya jika, Significance $F$ lebih besar dari tingkat kesalahan, maka dapat dikatakan bahwa variabel independen secara simultan tidak dapat dibuktikan berpengaruh terhadap variabel dependen.

Tabel 5. Hasil Uji Statistik F

\begin{tabular}{lrrrrr}
\hline & \multicolumn{1}{c}{$\boldsymbol{d} \boldsymbol{f}$} & \multicolumn{1}{c}{$\boldsymbol{S S}$} & $\boldsymbol{M S}$ & $\boldsymbol{F}$ & Significance $\boldsymbol{F}$ \\
\hline Regression & 3 & 0,77989594 & 0,259965313 & 16,71526377 & $6,59867 \mathrm{E}-07$ \\
Residual & 35 & 0,544339957 & 0,01555257 & & \\
Total & 38 & 1,324235897 & & & \\
\hline
\end{tabular}


Sumber: Hasil olahan statistik

Perhitungan Uji Statistik F, dapat menjawab hipotesis keempat $\left(\mathrm{H}_{4}\right)$, dalam penelitian ini, dimana:

\section{Hipotesis Keempat $\left(\mathrm{H}_{4}\right)$}

Berdasarkan hasil perhitungan uji f, diperoleh nilai signifikansi (Significance $F$ ) variabel independen lebih kecil dari tingkat kesalahan penelitian $(0,000000659867<0,05)$. Hal ini menunjukkan bahwa secara statistik profitabilitas, ukuran perusahaan dan kebijakan dividen secara simultan dapat dibuktikan berpengaruh terhadap nilai perusahaan, sehingga dapat dikatakan bahwa $\mathbf{H}_{\mathbf{0}-4}$ ditolak dan $\mathbf{H}_{\mathbf{1 - 4}}$ diterima.

Hasil penelitian ini sejalan dengan penelitian sebelumnya yang dilakukan oleh Berliani (2020) yang menyatakan bahwa profitabilitas, ukuran perusahaan dan kebijakan dividen berpengaruh terhadap nilai perusahaan secara simultan.

\subsection{Hasil Analisis Regresi Linear Berganda}

\section{Tabel 6. Hasil Regresi Linear Berganda}

\begin{tabular}{lr}
\hline \multicolumn{2}{c}{ Regression Statistics } \\
\hline Multiple R & 0,767424485 \\
R Square & 0,58894034 \\
Adjusted R Square & 0,553706655 \\
Standard Error & 0,124709944 \\
Observations & 39 \\
\hline
\end{tabular}

\begin{tabular}{|c|c|c|c|c|c|}
\hline & $d f$ & $S S$ & $M S$ & $F$ & Significance $F$ \\
\hline Regression & 3 & 0,77989594 & 0,259965313 & 16,7152638 & $36,59867 \mathrm{E}-07$ \\
\hline Residual & 35 & 0,544339957 & 0,01555257 & & \\
\hline Total & 38 & 1,324235897 & & & \\
\hline
\end{tabular}

Coefficients Standard Error t Stat $\quad$ P-value $\quad$ Lower 95\% Upper 95\% Lower 95,0\% Upper 95,0\%

\begin{tabular}{llrllllll}
\hline Intercept (Nilai Perusahaan) & 0,122806262 & 0,49116875 & 0,250028655 & 0,80402697 & $-0,87431931$ & 1,11993183 & $-0,87431931$ & 1,11993183
\end{tabular}

$\begin{array}{llllllllll}\text { X Variable 1 (ROA) } & 0,150200728 & 0,029342859 & 5,118817044 & 1,1201 \mathrm{E}-05 & 0,090631557 & 0,2097699 & 0,090631557 & 0,2097699\end{array}$

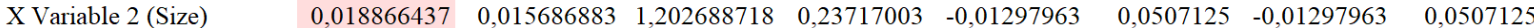

\begin{tabular}{llllllllll}
$\mathrm{X}$ Variable 3 (DPR) & $-0,08746246$ & 0,156947102 & $-0,55727347$ & 0,58088731 & $-0,40608201$ & 0,2311571 & $-0,40608201$ & 0,2311571 \\
\hline
\end{tabular}

Sumber: Hasil olahan statistik

Berdasarkan tabel hasil olah data di atas, diperoleh persamaan regresi linear berganda sebagai berikut:

$$
\begin{gathered}
y=a+b_{1} x_{1}+b_{2} x_{2}+b_{3} x_{3}+e \\
y=0,123+0,150 x_{1}+0,019 x_{2}-0,087 x_{3}+e
\end{gathered}
$$

Keterangan:

$$
\begin{array}{ll}
\mathrm{Y} & =\text { Nilai Perusahaan } \\
\mathrm{a} & =\text { Konstanta } \\
\mathrm{b}_{\mathrm{n}} & =\text { Koefisien Regresi Variabel Independen } \\
\mathrm{X}_{1} & =\text { Profitabilitas } \\
\mathrm{X}_{2} & =\text { Ukuran Perusahaan } \\
\mathrm{X}_{3} & =\text { Kebijakan Dividen } \\
\mathrm{e} & =\text { Error }
\end{array}
$$

Berdasarkan persamaan regresi tersebut, dapat dijelaskan seperti berikut ini: 
a. Konstanta sebesar 0,123 berarti jika profitabilitas $\left(\mathrm{X}_{1}\right)$, ukuran perusahaan $\left(\mathrm{X}_{2}\right)$ dan kebijakan dividen $\left(\mathrm{X}_{3}\right)$ bernilai nol (0), maka nilai perusahaan akan bernilai 0,123.

b. Koefisien regresi variabel $\mathrm{X}_{1}$, yaitu profitabilitas, menunjukkan nilai 0,150 yang menunjukkan arah positif yang artinya jika nilai variabel independen lain tetap dan variabel profitabilitas meningkat 1 poin, maka nilai perusahaan akan meningkat sebesar 0,150 poin.

c. Koefisien regresi variabel $X_{2}$, yaitu ukuran perusahaan, menunjukkan nilai 0,019 yang menunjukkan arah positif yang artinya jika nilai variabel independen lain tetap dan variabel ukuran perusahaan meningkat 1 poin, maka nilai perusahaan akan meningkat sebesar 0,019 poin.

d. Koefisien regresi variabel $X_{3}$, yaitu kebijakan dividen, menunjukkan nilai -0,087 yang menunjukkan arah negatif yang artinya jika nilai variabel independen lain tetap dan variabel kebijakan dividen meningkat 1 poin, maka nilai perusahaan akan turun atau berkurang sebesar 0,087 poin.

\subsection{Hasil Koefisien Determinasi $\left(\mathrm{R}^{2}\right)$}

Tabel 7. Hasil Uji Koefisien Determinasi

\begin{tabular}{lr}
\hline \multicolumn{2}{c}{ Regression Statistics } \\
\hline Multiple R & 0,767424485 \\
R Square & 0,58894034 \\
Adjusted R Square & 0,553706655 \\
Standard Error & 0,124709944 \\
Observations & 39 \\
\hline
\end{tabular}

Sumber: Hasil olahan statistik

Berdasarkan tabel hasil perhitungan di atas, diperoleh nilai Adjusted $\mathrm{R}^{2}$ sebesar 0,5537 atau sebesar 55,37\%. Hal ini menunjukkan bahwa variabel dependen (nilai perusahaan) dipengaruhi oleh variabel-variabel independen (profitabilitas, ukuran perusahaan, dan kebijakan dividen) sebesar 55,37\%. Sedangkan, sisanya sebesar 44,63\% dipengaruhi oleh faktor-fakor lain di luar penelitian ini. Kemudian, nilai standard error pada tabel di atas, yaitu 0,1247, menunjukkan kemungkinan terjadinya kesalahan dalam memprediksi variabel dependen dalam penelitian ini, yakni nilai perusahaan.

\subsection{Pembahasan Hasil}

\section{$\mathrm{H}_{1}$ : Pengaruh Profitabilitas terhadap Nilai Perusahaan Perbankan yang terdaftar di Bursa Efek Indonesia (BEI).}

Hasil uji statistik t menunjukkan bahwa profitabilitas dapat dibuktikan berpengaruh terhadap nilai perusahaan perbankan yang terdaftar di Bursa Efek Indonesia (BEI), artinya $\mathrm{H}_{1}$ penelitian ini diterima. Profitabilitas dapat berpengaruh terhadap nilai perusahaan karena dengan profitabilitas yang tinggi akan mengindikasikan prospek perusahaan yang baik yang kemudian akan memberikan persepsi positif dari para investor, hal ini dapat memicu meningkatkan permintaan (demand) saham perusahaan terkait. Selanjutnya, permintaan saham yang meningkat akan menyebabkan nilai perusahaan ikut meningkat. Semakin tingginya profitabilitas perusahaan maka laba perusahaan juga akan meningkat, laba yang lebih besar akan dampak positif terhadap peningkatan harga saham dan memperlihatkan bahwa kondisi perusahaan itu baik, sehingga dapat membantu menarik investor dan calon investor dalam berinvestasi atau dengan kata lain akan membuat investor tertarik untuk menanamkan modalnya dengan membeli saham perusahaan. Dengan banyaknya investor yang membeli saham 
perusahaan maka akan menaikkan harga saham perusahaan tersebut sehingga akan meningkatkan pula nilai perusahaan.

\section{$\mathrm{H}_{2}$ : Pengaruh Ukuran Perusahaan terhadap Nilai Perusahaan Perbankan yang terdaftar di Bursa Efek Indonesia (BEI).}

Hasil uji statistik t menunjukkan bahwa ukuran perusahaan tidak dapat dibuktikan berpengaruh terhadap nilai perusahaan perbankan yang terdaftar di Bursa Efek Indonesia (BEI), artinya $\mathrm{H}_{2}$ penelitian ini ditolak. Ukuran perusahaan tidak berpengaruh terhadap nilai perusahaan kemungkinan dikarenakan ukuran perusahaan dinilai dari total aset yang dimiliki oleh perusahaan untuk kegiatan operasionalnya, semakin besar ukuran perusahaan akan semakin besar pula dana yang dibutuhkan untuk kegiatan operasionalnya. Sementara, perusahaan memperoleh sumber dana salah satunya lewat utang pada pihak eksternal, maka semakin besar ukuran perusahaan kemungkinan besar akan semakin besar pula utangnya. Dengan besarnya utang, maka risiko perusahaan pun meningkat. Tingginya risiko dalam perusahaan tersebut dianggap dapat memperbesar potensi terjadinya kebangkrutan sehingga menimbulkan sinyal negatif bagi para investor dan nilai perusahaan pun tidak meningkat. Selain itu, banyak pula investor yang tidak mempertimbangkan atau memperhatikan besar kecilnya suatu bank ketika akan melakukan investasi. Bank berukuran besar belum tentu menjamin bank tersebut memiliki prospek yang pasti baik dan sebaliknya. Bank besar biasanya merupakan bank yang sudah lama berdiri. Di era digitalisasi seperti sekarang ini, tidak menjamin bank besar mampu beradaptasi dengan cepat. Mungkin saja bank besar justru lebih sulit untuk berubah mengikuti zaman. Ukuran bank juga tidak dapat dilihat dari sisi aset saja, karena kegiatan operasi utama bank yaitu menghimpun dana nasabah salah satunya dalam bentuk tabungan. Tabungan nasabah ini dicatat sebagai utang oleh pihak bank. Bank yang dapat menghimpun dana yang banyak, yang artinya utangnya pun besar, dianggap sebagai bank yang dipercaya oleh nasabah, bank besar dan nilai perusahaannya pun kemungkinan akan meningkat.

\section{$\mathrm{H}_{3}$ : Pengaruh Kebijakan Dividen terhadap Nilai Perusahaan Perbankan yang terdaftar di Bursa Efek Indonesia (BEI).}

Hasil uji statistik $\mathrm{t}$ menunjukkan bahwa kebijakan dividen tidak dapat dibuktikan berpengaruh terhadap nilai perusahaan perbankan yang terdaftar di Bursa Efek Indonesia (BEI), artinya $\mathrm{H}_{3}$ penelitian ini ditolak. Hal ini kemungkinan besar disebabkan karena ketika perusahaan tidak mampu menghasilkan laba secara konsisten, maka perusahaan tidak akan membagikan dividen. Ketidakstabilan pembagian dividen pada setiap periode akan berpengaruh terhadap menurunnya harga saham. Harga saham yang menurun dapat mengindikasikan nilai perusahaan yang juga menurun. Selain itu, ketika melakukan investasi di bursa saham atau pasar modal tidak semua investor memilih untuk memperoleh return lewat dividen, ada pula investorinvestor yang lebih memilih untuk memperoleh return dari capital gain, yaitu keuntungan yang diperoleh seorang investor dari hasil penjualan saham ketika harga penjualan saham lebih besar dari harga pembelian saham.

\section{$\mathrm{H}_{4}$ : Pengaruh Profitabilitas, Ukuran Perusahaan dan Kebijakan Dividen terhadap Nilai Perusahaan Perbankan yang terdaftar di Bursa Efek Indonesia (BEI).}

Hasil uji statistik f menunjukkan bahwa profitabilitas, ukuran perusahaan, dan kebijakan dividen secara simultan dapat dibuktikan berpengaruh terhadap nilai perusahaan perbankan yang terdaftar di Bursa Efek Indonesia (BEI), artinya $\mathrm{H}_{4}$ penelitian ini diterima. Profitabilitas yang dihitung dengan indikator ROA, akan besar jika perusahaan berhasil memaksimalkan 


\section{8 | Bina Ekonomi}

sumber daya atau aset yang dimilikinya menjadi laba. Profitabilitas yang tinggi akan memberikan indikasi prospek perusahaan yang baik sehingga dapat memicu investor untuk ikut meningkatkan permintaan saham dan akan menyebabkan nilai perusahaan meningkat. Kemudian, ukuran perusahaan merupakan salah satu indikasi untuk mengukur kinerja suatu perusahaan. Ukuran perusahaan diukur dari total aset perusahaan, bisa saja komponen dominannya bukan kas sehingga perusahaan belum tentu dapat membayar dividen. Biasanya perusahaan akan lebih mempertahankan atau menjaga laba dibandingkan membagikannya sebagai dividen, hal ini dapat mempengaruhi harga saham atau nilai perusahaan. Selain itu, perusahaan dengan ukuran besar pun tidak menjamin perusahaan tersebut kinerjanya baik, di mana kinerja perusahaan yang baik akan dapat meningkatkan nilai perusahaan. Sementara, kebijakan dividen merupakan persentase laba yang dibayarkan kepada pemegang saham, jika dividen tidak dibayarkan secara rutin dan jumlah dividen yang dibayarkan tidak stabil, hal ini justru dapat menurunkan nilai perusahaan. Meskipun dengan ukuran perusahaan yang kecil dan persentase laba yang diberikan perusahaan tidak terlalu besar dan tidak stabil, tetapi perusahaan atau bank tersebut masih profitable, yang ditunjukkan dengan rasio profitabilitas yang baik, maka para investor masih akan tertarik untuk berinvestasi pada bank tersebut, hal ini menunjukkan nilai perusahaan akan naik.

\section{KESIMPULAN}

Berdasarkan hasil penelitian dan pengujian yang telah dilakukan terkait pengaruh profitabilitas, ukuran perusahaan, dan kebijakan dividen terhadap nilai perusahaan perbankan yang terdaftar di BEI tahun 2017-2019, diperoleh kesimpulan sebagai berikut:

1. Profitabilitas dapat dibuktikan berpengaruh terhadap nilai perusahaan perbankan yang terdaftar di BEI tahun 2017-2019. Dapat diketahui dari hasil uji T yang dilakukan terhadap hipotesis pertama yang menyatakan bahwa hipotesis diterima.

2. Ukuran perusahaan tidak dapat dibuktikan berpengaruh terhadap nilai perusahaan perbankan yang terdaftar di BEI tahun 2017-2019. Dapat diketahui dari hasil uji T yang dilakukan terhadap hipotesis kedua yang menyatakan bahwa hipotesis ditolak.

3. Kebijakan dividen tidak dapat dibuktikan berpengaruh terhadap nilai perusahaan perbankan yang terdaftar di BEI tahun 2017-2019. Dapat diketahui dari hasil uji T yang dilakukan terhadap hipotesis ketiga yang menyatakan bahwa hipotesis ditolak.

4. Profitabilitas, ukuran perusahaan, dan kebijakan dividen dapat dibuktikan berpengaruh secara simultan terhadap nilai perusahaan perbankan yang terdaftar di BEI tahun 20172019. Dapat diketahui dari hasil uji F yang dilakukan terhadap hipotesis keempat yang menyatakan bahwa hipotesis diterima.

\subsection{Implikasi dan Keterbatasan}

Berdasarkan hasil penelitian dan pengujian yang telah dilakukan serta kesimpulan yang telah diperoleh terkait pengaruh profitabilitas, ukuran perusahaan, dan kebijakan dividen terhadap nilai perusahaan perbankan yang terdaftar di BEI tahun 2017-2019, berikut beberapa hal yang dapat diberikan:

1. Bagi investor dan calon investor, ketika akan melakukan keputusan investasi disarankan untuk memperhatikan pula variabel lain di luar profitabilitas, ukuran perusahaan, dan kebijakan dividen, karena masih terdapat variabel lain yang mungkin lebih mempengaruhi nilai perusahaan. Dengan begitu, diharapkan keputusan investasi yang dilakukan dapat lebih tepat. 
2. Bagi perusahaan, disarankan untuk terus mempertahankan atau bahkan meningkatkan kinerjanya sehingga investor dapat lebih tertarik untuk melakukan investasi.

3. Penelitian ini memiliki keterbatasan jumlah perusahaan yang diteliti dan periode waktu yang dipilih. Bagi peneliti selanjutnya, disarankan untuk menambah atau memperluas sampel penelitian, memilih sampel penelitian dengan industri yang berbeda, memilih periode tahun yang berbeda serta mempertimbangkan variabel independen lain yang kemungkinan berpengaruh terhadap nilai perusahaan ketika akan melakukan penelitian sejenis agar hasil penelitian dapat lebih digeneralisasi.

\section{DAFTAR PUSTAKA}

Adli, N., \& Hidayat, P. (2012). Studi Tentang Keputusan Nasabah Dalam Menabung Di Bank Sumut Cabang Usu Medan Metode Analytical Hierarchy Process (AHP). Jurnal Ekonomi dan Keuangan, 1(1), 14-21.

Aisyatul, M. (2014). Pengaruh Profitabilitas terhadap Nilai Perusahaan dengan Corporate Social Responsibility sebagai Variabel Moderating. Jurnal Ilmu dan Riset Akuntansi, 3(4).

Analisa, Y. (2011). Pengaruh Ukuran Perusahaan, Leverage, Profitabilitas dan Kebijakan Dividen Terhadap Nilai Perusahaan. Skripsi, Fakultas Ekonomi Universitas Diponegoro Semarang.

Berliani, M. M. (2020). Pengaruh Profitabilitas, Ukuran Perusahaan dan Kebijakan Dividen terhadap Nilai Perusahaan pada Perusahaan Manufaktur yang Terdaftar di BEI Periode 2014-2017. Skripsi, Fakultas Ekonomi dan Bisnis Universitas Sumatera Utara, Akuntansi, Medan.

Brigham, E. F., \& Houston, J. (2011). Dasar-Dasar Manajemen Keuangan (Terjemahan). Jakarta: Salemba Empat.

Brigham, E., \& Houston, J. F. (2007). Essential of Financial Management. In D. o. Yulianto, Dasardasar Manajemen Keuangan. Jakarta: Salemba Empat.

Darmanto, A. (2015). Pengaruh Profitabilitas, Leverage, Kebijakan Dividen, Cash Holding, Ukuran Perusahaan dan Corporate Social Responsibility Terhadap Nilai Perusahaan. Skripsi, Universitas Islam Negeri Syarif Hidayatullah, Akuntansi, Jakarta.

Dewi, A. S., \& Wirajaya, A. (2013). Pengaruh Struktur Modal, Profitabilitas dan Ukuran Perusahaan terhadap Nilai Perusahaan. E-Journal Akuntansi Universitas Udayana, 358-372.

Harmono. (2014). Manajemen Keuangan Berbasis Balanced Scorecard Pendekatan Teori, Kasus dan Riset Bisnis. Jakarta: PT Bumi Aksara.

Hasan, M. I. (2002). Pokok-pokok Materi Metodologi Penelitian dan Aplikasinya. Jakarta: Ghalia Indonesia.

Hasnawati, S., \& Sawir, A. (2015). Keputusan Keuangan Ukuran Perusahaan, Struktur Kepemilikan dan Nilai Perusahaan Publik Indonesia. JMK, 17(1), 65-75.

Husnan, S. (2008). Manajemen Keuangan: Teori dan Penerapan. Yogyakarta : BPFE

Husnan, S., \& Pudjiastuti, E. (2015). Dasar-Dasar Manajemen Keuangan (7 ed.). Yogyakarta: UPP STIM YKPN. 
James, H. V., \& Wachowicz, J. M. (2005). Prinsip-prinsip Manajemen Keuangan (Fundamental of Financial Management). In D. o. Fitriasari. Jakarta: Salemba Empat.

Kasmir. (2008). Bank dan Lembaga Keuangan Lainnya. Jakarta: PT. Raja Grafindo Persada.

Kusumawati. (2005). Analisis Pengaruh Profitabilitas (ROE), Ukuran Perusahaan (Size) dan Leverage Keuangan Solvabilitas terhadap Tingkat Underpricing pada Perusahaan Perdana (Initial Public Offering/IP0) di Bursa Efek Jakarta. Utilitas, 13(1), 93-110.

Maharani, I. A. (2021). Pengaruh Rasio Profitabilitas, Leverage, dan Kebijakan Dividen terhadap Nilai Perusahaan. Jurnal Widya Manajemen, 3(1), 27-38.

Margareta, F. (2005). Manajemen Keuangan Investasi dan Sumber Dana Jangka Pendek. Jakarta: PT. Gramedia Widiasarana Indonesia.

Martha, L., Sogiroh, N. U., Magdalena, M., \& Febsri Susanti, Y. S. (2018). Profitabilitas dan Kebijakan Dividen terhadap Nilai Perusahaan. Jurnal Benefita, 227-238.

Mulyadi. (2006). Manajemen Keuangan Pendekatan Kuantitatif dan Kualitatif. Malang: Bayumedia Publishing.

Noviliyan. (2016). Pengaruh Profitabilitas, Ukuran Perusahaan, Kebijakan Dividen, Leverage, Price Earnings Ratio, dan Kebijakan Hutang terhadap Nilai Perusahaan. Skripsi, Fakultas Ekonomi dan Bisnis Universitas Muhammadiyah Surakarta.

Parhusip, H. A., Topowijono, \& Sulasmiyati, S. (2016). Pengaruh Struktur Modal dan Profitabilitas Terhadap Nilai Perusahaan. Jurnal Administrasi Bisnis (JAB), 37(2), 163-172.

Prasetyorini, B. F. (2013). Pengaruh Ukuran Perusahaan, Leverage, Price Earning Ratio dan Profitabilitas Terhadap Nilai Perusahaan. Jurnal Ilmu Manajemen, 1(1), 183-196.

Riyanto, B. (2001). Dasar-dasar Pembelajaran Perusahaan. Yogyakarta: Gadjah Mada University Press.

Romadhani, A., Saifi, M., \& Nuzula, N. F. (2020). Pengaruh Profitabilitas, Ukuran Perusahaan dan Kebijakan Dividen terhadap Nilai Perusahaan. Jurnal Administrasi Bisnis, 14(2), 71-81.

Salvatore, D. (2005). Ekonomi Manajerial dalam Perekonomian Global. Jakarta: Salemba Empat.

Siregar, M. E., Dalimunthe, S., \& Trijuniyanto, R. S. (2019). Pengaruh Profitabilitas, Ukuran Perusahaan, Kebijakan Dividen dan Struktur Modal Terhadap Nilai Perusahaan pada Perusahaan Manufaktur yang Terdaftar di Bursa Efek Indonesia Periode 2015-2017. Jurnal Riset Manajemen Sains Indonesia (JRMSI), 356-385. doi:doi.org/10.21009/JRMSI.010.2.07

Smithers, A., \& Wright, S. (2007). Valuing Wall Street. McGraw Hill.

Sofyan, H. (2015). Analisis Kritis Atas Laporan Keuangan. Jakarta: PT. Rajagrafindo Persada.

Sudana, I. M. (2011). Manajemen Keuangan Perusahaan Teori \& Praktik. Jakarta: Erlangga.

Suffah, R., \& Riduwan, A. (2016). Pengaruh Profitabilitas, Leverage, Ukuran Perusahaan dan Kebijakan Dividen pada Nilai Perusahaan. Jurnal Ilmu dan Riset Akuntansi, 5(2), 1-16. 
Sujoko, \& Soebiantoro, U. (2007, Februari). Pengaruh Struktur Kepemilikan Saham, Leverages, Faktor Intern dan Faktor Ekstern Terhadap Nilai Perusahaan (Studi Empiris Pada Perusahaan Manufaktur dan Non Manufaktur di Bursa Efek Jakarta). Jurnal Manajemen dan Kewirausahaan FE Universitas Kristen Petra, 9(1), 41-48.

Syamsuddin, L. (2011). Manajemen Keuangan Perusahaan. Jakarta: Rajawali Pers.

Wahyudi, H. D., Chuzaimah, \& Sugiarti, D. (2016, Desember). Pengaruh Ukuran Perusahaan, Profitabilitas, Kebijakan Dividen, dan Keputusan Investasi terhadap Nilai Perusahaan (Studi Penggunaan Indeks LQ-45 Periode 2010-2014). 1(2). 